\title{
RATIONALIZATION AND NATURAL LAW Max Weber's and Ernst Troeltsch's interpretation of the medieval doctrine of natural law
}

\author{
Ludger Honnefelder*
}

SÍNTESE - Max Weber e Troeltsch perceberam a importância que o conceito de direito natural, tal como $o$ entenderam os medievais, teve para a formação e desenvolvimento da civilização ocidental. Não se pode negar esta importância, mas os estudos posteriores mostram claramente que a leitura feita por aqueles dois cientistas necessita de diversas correções, principalmente quando se toma como paradigmática a obra de Tomás de Aquino.
ABSTRACT - Max Weber and Troeltsch have realized the importance of the natural law concept, according to the meaning of the Middle Ages and its influence on the occidental civilization. Such a relevance is undeniable. But later studies clearly show that the explanation of the above mentioned scientists needs some corrections, specially when Aquinas' work is taken as paradigmatical.

In Max Weber's and Ernst Troeltsch's interpretation of the religious and social development of Western civilization, the concept of natural law has a pivotal role. Weber's thesis runs as follows: in the reception and transformation of the Stoics's concept of natural law the Christian faith finds the key that makes it possible to mediate between the originally world-denying claims of the gospel and the "norms of the world". ${ }^{1}$ Since natural law must be regarded as having "the purest type of normative rational validity", ${ }^{2}$ its prevalence is of central importance for the rationalization that is linked to the Christian faith.

The backdrop for this thesis is provided by Troeltsch's far more detailed and extensive studies of the social doctrines of various Christian churches and groups. ${ }^{3}$ Troeltsch's interpretation runs as follows.

\footnotetext{
- University of Bonn
}

1 M. Weber, Wirtschaft und Gesellschaft. Grundriß der verstehenden Soziologie, Studienausgabe, ed.: J. Winckelmann, Tübingen ${ }^{5} 1972,497$.

2 M. Weber, fn. 2, 19.

3 Cf. E. Troeltsch, Die Soziallehren der christlichen Kirchen und Gruppen, Ges. Schriften 1, Tübingen 31923, esp. ch. 2: "Der mittelalterliche Katholizismus", 178-426. M. Weber refers to this in: in. 1, 360 .

\begin{tabular}{|l|l|l|l|l|l|} 
VERITAS & Porto Alegre & v. 40 & $\mathrm{n}^{\circ} 159$ & Setembro 1995 & p. $493-507$ \\
\hline
\end{tabular}


The reception of the Stoic concept of natural law is as crucial to Christian ethics as the reception of the concept of logos is to Christian dogmatics. ${ }^{4}$ Just as the concept of logos mediates between the truth of revelation and the truth of reason, so the concept of natural law mediates between the moral demands of the gospel and the principles of a worldly ethos. Since there is a distinction between an absolute natural law, which is identical with the radical ideal of the Sermon on the Mount, and a relative natural law, substantially corresponding to the ten commandments and the political and social reality, ${ }^{5}$ such a mediation, which must be oriented on the relative natural law, will needs qualify the original radical Christian claim. ${ }^{6}$ Whereas the old church allowed both forms of the natural law to stand alongside each other without mediation and was therefore unable to overcome their estrangement within the surrounding social reality, ${ }^{7}$ the Christian Middle Ages succeeded in uniting both forms by replacing the distinction between the gospel (or church) and the world with a distinction between the natural and the supernatural, ${ }^{8}$ interpreting each as a level of a metaphysical whole. ${ }^{9}$ When this idea of a metaphysical hierarchy of reality, attached to the concept of natural law, became linked to the notion of society as a structured organism, as taught by Aristotle and Paul, ${ }^{10}$ the concept of natural law assumed a virtually fundamental status: it grounded both moral ${ }^{11}$ and social ${ }^{12}$ philosophy and enabled the rise of the "unified culture" ${ }^{113}$ characteristic of the Christian Middle Ages, from which the reformation later departed in order to regain the radicalism of the gospel. ${ }^{14} \mathrm{By}$ linking the concept of natural law to the organic interpretation of the social, the Christian Middle Ages could also assign a central role to the church: just as the divine law is the bracket that binds together the levels of moral laws, so the church is the bracket that holds together the members of the social organism. ${ }^{15}$ Its interpretation as the "boundless, comprehensive, and guiding institution of salvation" ${ }^{16}$ together with the strong attachment of natural law to eternal and

4 Cf. E. Troeltsch, Aufsätze zur Geistesgeschichte und Religionssoziologie, Ges. Schriften 4, Tübingen ${ }^{3} 1925$, 21-649; cf. also: G. Becker, Neuzeitliche Subjektivität und Religiosität. Die religionsphilosophische Bedeutung von Heraufkunft und Wesen der Neuzeit im Denken von Emst Troeltsch, Regensburg 1982, $197 f$.

5 Cf. E. Troeltsch, fn. 4, 158f., 177f.; also: fn. 3, 178f., 253, 264.

6 Cf. E. Troeltsch, fn. 3, 252f. $275 \mathrm{ff}$.

7 Cf. E. Troeltsch, fn. 3, ch. 1: "Die Grundlagen in der alten Kirchen", 16-178.

8 Cf. E. Troeltsch, fn. 3, 264.

9 Cf. E. Troeltsch, fn. 3, 270, 284, 290, 303.

10 Cf. E. Troeltsch, in. 211, 296, 300, 304f., 320.

11 Cf. E. Troeltsch, fn. 3, $272 f$.

12 Cf. E. Troeltsch, fn. 3, 228f., 292 ff.

13 Cf. E. Troeltsch, fn. 3, 252, 273.

14 Cf. E. Troeltsch, fn. 3, ch. 3: "Der Protestantismus", 427-794.

15 Cf. E. Troeltsch, fn. 3, 178f., 182f., 209ff., 294f., 322.

16 "...die unabsehbar dauemde, das Gesamtleben umfassende und das Einzelleben lenkende Heilsanstalt"; Cf. E. Troeltsch, fn. 4, 212; cf. also 132ff. 
immutable principles, must, in the last consequence, lead to a "conservative, organically patriarchal natural law". ${ }^{17}$ Consequently, those elements that were already contained in the medieval form of the natural law but not in the Platonic interpretation of the social order, and which in its later secular form gave it its progressive, even revolutionary power, remain repressed: the idea of the dignity of a person, the associated freedom and autonomy of individual reason, the resulting responsibility of personal conscience, and the significance of one's vocation, which stems form the place of the individual within the whole. ${ }^{18}$

With the thesis that the doctrine of natural law represents an essential contribution of the Christian Middle Ages to the course of Western development, and that this contribution is particularly effective in the doctrine of natural law found in Thomas Aquinas, ${ }^{19}$ Troeltsch and Weber formulated an insight that stands the test of contemporary research, regardless of their highly questionable presentation of this doctrine in detail. In fact, only the massive corrections to Weber's and Troeltsch's interpretation, which must be made in the light of recent research, particularly on Thomas Aquinas, enable us to recognize the particularly significance of their insight. The following sections aim to show how much the pivotal role, which Weber and Troeltsch attribute to the concept of natural law, is part of the medieval doctrine itself. In particular, they deal with: (i) the place and status of the doctrine of natural law in Thomas Aquinas; (ii) the autonomy of reason, which follows from it; (iii) the relationship between the natural law and the historical ethos; (iv) the interpretation of the hierarchy of the moral with the help of the analogous meaning of the term 'law'; (v) and finally, the relationship between natural law, social order and individual conscience.

The first important correction to the details of the Troeltsch-Weber position derives from the place at which the doctrine of natural law appears in the doctrinal edifice of Thomas Aquinas and the status that he thereby accords to it. Like Augustine and the Stoics, Aquinas understands natural law as the specific way in which the rational creature participates in the eternal law of the plan of creation and providence, which is present in the mind of God. ${ }^{20}$ The reception of this concept, however, is shaped by the framework of Aristotles philosophy of science, which governed Aquinas's thought. As the prologue to the Thomistic commentary on the Nichomachean Ethics makes clear, Thomas concurred with Aristotle in presuming a plurality of sciences and an irreducible distinction between theoretical and practical reason, as well as between theoretical and practical science. ${ }^{21}$ Any derivation of ethics from metaphysics is thus excluded from the outset, as Kluxens

17 Cf. E. Troeltsch, fn. 3, 329.

18 F. E. Troeltschy, fn 3, 304f., 311, 319, 358.

19 Cf. E. Troeltsch, in. 3, 182f., 278f., 283, 311.

20 For an overview of the history of these terms cf. G. Wieland, Art. "Gesetz, ewiges", in: Hist. Wörterbuch der Philosophie 3, Basel/Stuttgart 1974, 514-516.

21 Cf. Thomas Aquinas, In Eth. prol. 
study has shown. ${ }^{22}$ Ethics has its own highest principles, which are coordinate, not subordinate to those of metaphysics. ${ }^{23}$ Only theology, which considers its object from that divine perspective that is available to humans because of revelation, is excepted from the distinction between theoretical and practical science.

The place at which Aquinas operates with the concept of "eternal law" (lex aeterna) is his theological reflection on the principles of human action, part of which is the tract on the law and its various forms in Summa Theologiae I-II. ${ }^{24}$ The theological perspective reveals reflexively, that the way in which all creatures, by their very nature, are guided towards their appropriate goal must have its base in the eternal law of Gods plan. Whereas for Augustine and the Stoics, who did not know the Aristotelian distinction between theoretical and practical knowledge, the eternal law has a practical character as an immediate guide to action, ${ }^{25}$ in Aquinas it only signifies a subsequent, speculative insight. Since, according to Aquinas, the participation of human reason in the eternal law consists not in any immediate knowledge of it but rather in nothing other than the possession of practical reason and its special capacities, the point of the doctrine of eternal law is to demonstrate, from a theological perspective, the autonomy of practical reason as knowledge that guides action. Natural law as participation in the eternal law means that human beings are following Gods plan by recognizing what is good and evil through their own practical reason and its principles. According to Aquinas, the theological perspective not only does not invalidate the autonomy of human reason and the distinction between theoretical and practical knowledge, which is bound up with it, on the contrary, it accords this autonomy its just place.

Troeltsch, in effect, reads the Thomistic doctrine according to the perspective of Augustine and the Stoics. He overlooks the influence of Aquinas' reception of Aristotle, which transformed the status of the doctrine, and as a result interprets Aquinas's ethics as an application of his metaphysics. He is led into this historical misconception by the neoscholastic Aquinas interpretation of his time. It, in turn, followed a conception of natural law that overlaid the original Thomistic doctrine during the early modern period, as seen for example in Christian Wolff. According to this conception, the natural law can be derived from a law of nature which in turn flows from the metaphysical interpretation of human nature. The deductive chain that results is impressively consistent and complete, but it is open to the objection either that it commits the naturalistic fallacy, be deriving 'ought' from 'is', or that it is begging the question, by according to human nature the properties that are deduced from it as normative conclusions. If one clears away the objection that what appears here as natural law is nothing but the Christian world of values by speaking of a "Christian natural law" from the outset, then one has simply introduced a non-concept and undermined, both historically and substantially, the

22 Cf. W. Kluxen, Philosophische Ethik bei Thomas von Aquin, Hamburg ${ }^{2} 1980$.

Cf. Thomas Aquinas, Summa Theologiae I-II, 94, 2.

Cf. in detail W. Kluxen, fn. 22, 1-107.

Cf. Augustine's phrase in: Contra Faustum 22, 27 (CSEL XXV 621): "Lex vero aeterna est ratio divina vel voluntas dei ordinem naturalem conservari iubens, perturbari vetans". 
original intention of the concept to express a rule of action which human beings accept as binding because of their very nature and not because of a positive act revealed to them.

Since both objections against the Wolffian portrait of natural law are justified, it is understandable that the doctrine of natural law. has come into discredit and been exiled to a home in the neighborhood of ideology. As recent studies quite clearly show, the objections indeed affect certain modern and neoscholastic forms of the doctrine, but not, despite $\mathrm{H}$. Welzels quite recent suggestions, ${ }^{26}$ Aquinas's doctrine itself. However, only if one takes the doctrine of natural law as a position independent of theological or metaphysical premises, as Aquinas did, will it become clear why he could attribute to it the status of a universal mediation, as Troeltsch and Weber claim.

\section{II}

This becomes clearer still after a second correction concerning the autonomy of practical reason, which is linked to the doctrine of natural law. Troeltsch was undoubtedly right in seeing the authoritative Biblical source of the medieval doctrine of natural law in the idea expressed in Romans 2, 14f. ${ }^{27}$ that "the Gentiles, who do not have the law, do by nature what the law demands" and must therefore be considered as people who "are a law unto themselves" because "the demands of the law are written into their hearts". If the Christian God is to be thought of as the universal creator and judge, then human beings must have the chance of a moral existence by virtue of the very nature given to them by divine creation. As Aquinas puts it in the prologue to Summa Theologiae I-II, their being made in the image of God consists in their ability "themselves to be the origin of their actions ${ }^{128}$ by virtue of their reason and freedom. However, the theological claim that human beings can recognize for themselves what is good and evil can only be maintained if it is evident on its own terms, i. e. if it is philosophically demonstrable.

Thomas furnishes such proof by developing a reflexive analysis of the application of practical reason in parallel to the reflexive analysis of the operation of theoretical reason, the rudiments of which are found in Aristotle. Just as theoretical reason has the given being (ens) as its object and understands what is the case, so practical reason has the desired good (bonum) as its object and understands what is to be done..$^{29}$ The result, in either case, is propositions which in the first case

\section{Cf. H. Welzel, Naturrecht und materiale Gerechtigkeit, Göttingen 41962, 57-66. \\ Cf. E. Troeltsch, fn. 4, 746.}

Thomas Aquinas, Summa Theologiae I-II prol.: "[...] homo factus ad imaginem Dei dicitur, secundum quod per imaginem significatur intellectuale ad arbitrio liberum et per se potestativum [...] secundum quod est suorum operum principium, quasi liberum arbitrium habens et suorum operum potestatem."

Cf. to this and the following: Thomas Aquinas, Summa Theologiae I-II, 94, 2; cf. in detail: L. Honnefelder, "Praktische Vernunft und Gewissen", in: A. Hertz et al. (eds.), Handbuch der christlichen Ethik 3, Freiburg/Basel/Vienna 1982, 19-43, 23ff.; "Wahrheit und Sittlichkeit. Zur Bedeutung der Wahrheit in der Ethik", in: E. Coreth (ed.). Wahrheit in Einheit und Vielheit, Düsseldorf 1987, 147-169. 
have the character of statements and in the other that of prescriptions or, as Aquinas says, of laws. Reflexive analysis shows that both forms of propositions have a common structure, namely that of yes/no-determination. In theoretical propositions something is attributed to an objector denied of it; in practical propositions an action, which relates to a particular desire, is prescribed to be done or to be refrained from. This distinction, which is revealed in the basic structure of theoretical and practical sentences has the character of a basic rule of the application of reason, the character of a highest and first formal principle. For theoretical reason, the distinction between true and false is manifest in the principle of excluded contradiction that all propositions that are to state something must obey. For practical reason, the distinction between to be done and to be refrained from, i. e., the distinction between good and evil, is manifest in the highest practical principle that all prescriptive propositions must obey. For to attribute a characteristic to an object and to deny that characteristic of it at the same time would mean to state nothing about the object; and to prescribe an action, which relates to a particular desire as to be done and to be refrained from at the same time would mean not to give any guidance for action at all. Like the principle of the excluded contradiction, the highest practical principle is "constituted by reason" as a law or rule; and like all first principles it is one of those propositions that are evident in themselves and are therefore to be considered as propositions that are "naturally" or "originally" understood. Consequently, Aquinas can interpret the understanding of the first practical principle: to do good and refrain from evil, as a "natural habit", which is originally imprinted upon our faculty of practical reason. In accordance with a long tradition, he calls this the synderesis or original conscience. ${ }^{30}$

With the assumption of this first practical principle, Aquinas expressed nothing other than the thesis, common to all ethical theories, that moral understanding is always acknowledgment, and that something has been understood as morally good, if it has been acknowledged as a claim that is agreed to and thus becomes binding for ones own action. Consequently, reason can only give guidance for action insofar it is applied under the highest rule in which, prior to any concrete judgment that guides the action, it establishes a fundamental content that is necessarily contained in all more specific practical contents and which represents the form of all concrete rules, namely to do what is acknowledged as good and refrain from what is acknowledged as evil.

This principle expresses the fundamental structure of practical rationality or, to put it in another way, it expresses the rationale of acting as such, insofar as acting signifies that part of reality, which occurs because it arises from the will in a considered way, i. e. from the determination of the will by reason, as Aquinas stresses in his elaboration on the Aristotelian approach. ${ }^{31}$ And if acting rationally means to place oneself under the distinction between good and evil, then the acknowledgment of this principle is equivalent to the acknowledgment of the

30 Cf. Thomas Aquinas, Summa Theologiae I-II, 94, 2; I-II, 63, 1; I 79, 12; De Veritate 16, 1.

31 Cf. Thomas Aquinas, Summa Theologiae I-II, 1, 1; I; 83, 1. 

follow reason. ${ }^{32}$

If one is not to misunderstand the scope of the first practical principle, one must consider what it entails and what it does not entail. Arrived at by way of reduction, it turns out to be the formal structure of all concrete practical judgment, not, however, their source. No concrete sentence which guides action is possible without implying this principle, but none can be directly deduced from it either. ${ }^{33}$ As regards material content, the principle is tautological and empty.

But what is the good that is to be done? To begin with, the answer can only be: that which is good for human beings and which can be brought about by them, i. e., the praxis that fulfills and realizes their natural potential. But that which is their natural potential can only be understood in outline, by determining the fundamental desires, or inclinationes naturales, of the human being. ${ }^{34}$ As Aquinas's examples: the desire to survive, the desire to reproduce, and the desire to know, especially the truth about God, show no concrete norms can be derived from or read out of them. They have a meta-normative character and form a "natural system of rules, which is open to intent", "a non-arbitrary, open teleological system", as Korff puts it, ${ }^{35}$ from which only the most general prohibitions, which set natural boundaries to the field of action, can be gleaned, not, however concrete and positive guides to action. Consequently, the good that is to be done does not simply result from the ends that rule our natural desires, but from the ends which reason arrives at in a complex practical deliberation, the so-called practical syllogism, and which it presents to the will as worth desiring. This practical deliberation takes place in light of the highest practical principle and in view of the fundamental human desires. Since, however, reason and fundamental desires are not results of action but its presuppositions, Aquinas calls their possession "natural law" and the most general rule derived from them "the first commandments of natural law" (prima praecepta legis naturalis). ${ }^{36}$

Since the human will is bound to that which reason presents to it as worthy of desire, the obligatory force of all commandments does not simply flows from nature but only from "the instruction of reason itself" (ex ipso dictamine rationis). ${ }^{37}$ "Natural reason commands one and all to act according to reason". ${ }^{38}$ It is "the ordering force for everything that concerns human beings". ${ }^{39}$ If, however, human

32 Thomas Aquinas, Summa Theologiae I-II, 18, 5; I-II, 94, 3; I-II, 54, 3.

33 Cf. in detail, K. -M. Merks, Theologische Grundlegung der sittlichen Autonomie. Strukturmomente eines 'autonomen' Normenbegründungsverständnisses im lex-Traktat der Summa Theologiae des Thomas von Aquin, Düsseldorf 1978, 240-279.

34 Cf. Thomas Aquinas, Summa Theologiae I-II, 104, 1; I-II, 92, 1; I-II, 94, 4, 3; II Sent. 39, 3 , 3.

35 W. Korff, Norm und Sittlichkeit. Untersuchungen zur Logik der normativen Vernunft, Freiburg ${ }^{2} 1985$, 51, 72-112.

36 Cf. fn. 34.

37 Thomas Aquinas, Summa Theologiae I-II, 104, 1; 92, 1, 2; I-II, 94, 4, 3; II. Sent. 39, 3, 3.

38 Thomas Aquinas, Summa Theologiae II-II, 47, 7.

39 Thomas Aquinas, Summa Theologiae I-II, 94, 2, 3. 
beings do not simply grasp the ends of their desire in order to follow them, as even the animals do, but instead know of the ends as ends and act by taking a stand towards them, then this reflexive relationship to themselves, which is made possible by reason, is the "whole origin of freedom" (totius libertatis radix). ${ }^{40}$ According to Aquinas, freedom is displayed in the binding of the will to reason and truth: "Those who refrain from evil deeds not because they are evil, but (only) because God so commands, are not free". ${ }^{41}$

Natural law, Weber observes, is "the essence of all norms, which are independent of and preeminently valid relative to any positive law, which owe their dignity not to any arbitrary statute, but which conversely warrant the binding force of such a statute; in other words, norms, which are legitimate not due to their origin from a legitimate law maker but to immanent qualities: the specific and solely consequent form of legitimacy of a law, which can remain when religious revelations and the authoritative sanctity of tradition and its bearers fall away. ${ }^{42}$ This first happens explicitly in modern times. But Weber clearly recognizes that the historical precondition for this process is the discovery or the "law for all' warranted by God's will, in contrast to the commandment revealed directly by God to his confessors and plausible only to the chosen". ${ }^{43}$ However, this is precisely what Aquinas achieved: from the perspective of theonomy, i. e., the "eternal law", it is clear that the mode in which human beings participate in this law is that of autonomy, i. e., the "natural law". However, Aquinas not only realizes that a "law for all", which all human beings possess because of their rational nature, must be understandable for all, i. e., independently of the revelation of the divine will; as has been shown, he also succeeds, by elaborating on the Aristotelian doctrine of practical reason, in showing that and how the natural law can indeed be understood by everyone, independently of whether or not they believe.

The transition from "lex aeterna type natural law" to the "autarchic natural law", as described by R. Specht, ${ }^{44}$ first took place not in the modern period but in the step which Aquinas, with the help of Aristotle, took beyond Augustine. Thus, late scholastic authors such as G. Biel, F. de Vitoria, D. Soto and F. Suárez could legitimately employ the phrase: etsi per impossibile daremus non esse Deum (even if one were to admit - and it is an impossible admission - that God does not exist), which is found in Grotius and counts as typically modern. ${ }^{45}$ For they are saying nothing substantially different from that which is found in Aquinas. G. Vázquez seeks to heighten the innate autonomy of the morally normative still further by having the lawfulness that underlies natural law precede every, even God's, act of

40 Thomas Aquinas, De Veritate 24, 2.

41 Thomas Aquinas, Expos. super II epist. ad. Cor. 3, 2.

42 M. Weber, fn. 1, 497.

43 Ibid.

44 Cf. R. Specht, "Uber philosophische und-theologische Voraussetzungen der scholastischen Naturrechtslehre", in: F. Böckle/E. -W. Böckenförde (eds.), Naturrecht in der Kritik, Mainz 1973, 39$60,45 f$.

45 Cf. R. Specht, fn. $44,48$. 
understanding and willing in a way that is not found in Aquinas; and he sees this autonomy as grounded solely in the non-contradictory guises of the nature of the thing itself. ${ }^{46}$ Summarily speaking, natural law appears as that which Weber describes in characterizing it as "identical with the "nature of the thing itself" and as "rules which 'even God cannot change'". ${ }^{47}$

\section{III}

The third point at which Weber's and Troeltschs interpretation of the medieval doctrine of natural law must be corrected and extended in view of the more recent interpretations of the Thomistic doctrine, concerns the relationship between natural law and ethos and therefore the relationship between natural law and history. As far as one can gather from the texts, Troeltsch understood medieval natural law to be a system that can be derived deductively from metaphysical premises, and obviously saw the cohesion of the "unified culture" of the Middle Ages explained by this. ${ }^{48} \mathrm{He}$ saw no difference between the Thomistic doctrine and the catholic, i. e., the neo-thomistic/neo-scholastic, social philosophy of his time. "Until today, the equivalent of the natural/super-natural hierarchy of the cosmos is a corporative and hierarchical view of society as well as a hierarchical morality of the estates in their relation to the absolute ideal; the task of coordinating and unifying these different moral motives calls for a guiding authority which draws up dogmatically and morally clear and absolutely binding rules which relieves the individual of the labor of adjustment and rules the entire life as an authority". ${ }^{49}$

As research has shown, the neo-scholastic concept of unity was foreign to Aquinas. What Troeltsch calls the "unified culture of the Middle Ages" is for Aquinas not the result of a uni-linear deduction from a single principle but the result of a very complex mediation between different things. As mentioned before, Aquinas not only did not know a deduction of ethics from metaphysics; he also sees the path to gaining concrete rules for action differently to what Troeltsch's interpretation suggests. Because the "highest rule" only indicates the most general principle of moral acknowledgment, and the "natural desires" only the outlines of goals which realizes human possibility, little can be gained by way of deducing conclusions from principles. To gain concrete rules for action a second process is needed which Aquinas calls the "further determination of general sentences" (determinatio aliquorum communium). ${ }^{50}$ What he means is the method of understanding, which Aristotle calls "prudence" (phronesis) and which Aquinas

46 Cf. J. M. Galparsoro Zurutuza, Die vernunftbegabte Natur, Norm des Sittichen und Grund der Sollensforderung. Systematische Untersuchung der Naturrechtslehre Gabriel Vázquez. Diss. Bonn 1972, esp. 196-198; F. Böckle, Natürliches Gesetz als göttliches Gesetz in der Moraltheologie, in: F. Böckle/E. -W. Böckenförde (eds.), fn. 44, 165-188, $183 f f$.

47 M. Weber, fn. 1, 496.

48 Cf. E. Troeltsch, fn. 3, 248ff.; 225; cf. also fn. 13.

49 E. Troeltsch, in. 3, 284.

50 Cf. Thomas Aquinas, Summa Theologiae I-II, 95, 2; 95, 4; 100, 11. 
retains under the title of prudentia, a method that looks for the suitable means to an end by employing a practical syllogism and results in a final practical, action-guiding judgment. ${ }^{51}$

This practical syllogism differs from a theoretical deduction in a number of characteristic ways. For unlike theoretical reason, practical reason does not deal with unchangeable facts. As Aquinas, following Aristotle; stresses, its object is an individual action, which not only is not necessary but also absolutely singular and because of its singularity, like any other individual, inaccessible to conceptual, scientific investigation. Thus, in the practical realm, there is a strictly universal and necessary knowledge only with respect to the highest general principles and the general prohibitions that directly follow them. The further practical reason descends into the realm of the individual, the larger the area of plurality and change, and the more possible error becomes. ${ }^{52}$ The practical syllogism, which leads to the final practical judgment of a concrete rule for acting, does not just subsume means to a given end, but mediates between the commanded end and the concrete situation by designing and testing the options for acting which will lead to the commanded ends. For, as Aquinas stresses, there is not just one means that will lead to the end in question. However, if the means are many and contingent, then the truth of the conclusion cannot be proven with the same degree of necessity as in proofs of theoretical reason, which allow strictly one medium term only. ${ }^{53}$ The "determination" of the first commandments of natural law through human or divine laws has the character of an extension and is impossible without some "invention". ${ }^{54}$ This has to take account of historical accretions and transformations. Thus, the result of the "determination" is not an ethos, which is ahistorical and immutable in the last detail, but a concrete historical ethos, which becomes manifest in certain virtues.

Troeltsch is right in suggesting that Aquinas knows a number of levels at which the natural law unfolds. Yet this plurality of levels does not follow from the hierarchical structure of reality but from the process of practical reasoning. Underlying it is the distinction to be drawn between a concrete judgment of action and its principles, between the positing of concrete rules and the rules that govern this positing. This distinction makes it possible to separate the realm of principles that are immutable and unified from the realm of concrete judgment of action in which change and plurality are possible. ${ }^{55}$ However, if a concrete ethos cannot simply be deduced from the commandments of the natural law but instead requires design, then it is consistent that Aquinas develops the concrete theological ethics of Summa Theologiae II-II not as an ethics of laws but, following the Aristotelian example, as an ethics of virtues.

Cf. Thomas Aquinas, Summa Theologiae II-II, 47.

Cf. Thomas Aquinas, Summa Theologiae I, 47, 1, 3; I-II, 14, 1; I. 82, 2.

Cf. Thomas Aquinas, Summa Theologiae I-II, 91, 3; 94, 3 and 5; 95, 2; cf. also W. Kluxen, fn. 22, 235.

Cf. fn. 52 . 
What gives natural law its universal mediating function, of which Weber and Troeltsch rightly speak, is therefore not a unified, deductively unfoldable system of derivation, but rather the distinction between principle and concrete rule, between law and virtue, between principles of action and a plan of action. The "unified culture" of the Christian Middle Ages which Troeltsch conjures up is, in terms of morality, the unity of an ethos-design; and only to the degree to which this unity dissolves does it become the unity of the principles. Thus in late Spanish scholasticism, which is already influenced by the dissolution of this unity, an attempt to formulate an ethics of laws based on the principle of natural law emerges in place of an ethics of virtues. The treatise on law, a reflection on principles with which Aquinas retrospectively prefaces his ethics of virtue, becomes the ground on which an ethics is developed.

\section{IV}

The fourth point of correction concerns Troeltsch's interpretation of the natural law doctrine insofar as it refers to the relationship between the natural and the supernatural. The relationship between natural law and positive divine law, especially in the guise of the "new law", the lex evangelii, is for Aquinas undoubtedly a case of the relationship between nature and grace; and the axiom: gratia supponit ac perficit naturam, to which Troeltsch refers, ${ }^{56}$ is also undoubtedly genuinely Thomistic. Yet significantly, Aquinas does not establish the relationship between natural law and the law of the gospel by appeal to a higher concept of "nature", as would be the case in an interpretation according to the schema of natural-supernatural, but by appeal to the concept of law. In the prominence he gives to the conceptual pair natural-supernatural, much as in his understanding of the church as an "institution" and the locus of papal infallibility, Troeltsch follows entirely the pattern of neoscholastic theology as expressed in the conceptual idiom of Vatican I.

As the studies of U. Kühn and O. H. Pesch have shown, ${ }^{57}$ Aquinas prefers the concept of law because, contrary to the static concept of nature, it allows to describe the relationship historically. For if one applies the four aspects of the concept of law: determination by reason, reference to the common good, lawgiver and promulgation, ${ }^{58}$ which Aquinas arrives at inductively, in an analogous fashion, then the normative structure of practical reason can be interpreted as law through creation, to which the human law and even more so the old and the new law of God can be related as further historical items. According to Aquinas, the different laws correspond to different "times": the time of nature, the time of the (old) law,

56 Cf. E. Troeltsch, fn. 4, 178ff.; fn. 3, 264 .

57 Cf. U. Kühn, Via cantatis. Theologie des Gesetzes bei Thomas von Aquin, Berlin 1964; O. H. Pesch, Die Rechtfertigungslehre bei Thomas und Luther. Versuch eines systematisch-theologischen Dialogs, Mainz 1967.

58 Cf. Thomas Aquinas, Summa Theologiae I-II, 90, 1-4. 
and the time of grace, i. e., of the new law. ${ }^{59}$ This corresponds to the overall structure of the Summa Theologiae for which Aquinas, by using the neoplatonic schema of egressus-regressus, takes the idea of the history of salvation as a basis, not, as in Bonaventure, by tracing its course but by following the structure of this course. $^{60}$

Aquinas's account is therefore exactly the reverse of what Troeltsch describes. The "absolute natural law" is not the ideal revealed and demanded by the Sermon on the Mount and the "relative natural law" its weaker version, which takes account of the circumstances. ${ }^{61}$ What Aquinas calls natural law is the open structure of principles that is part of human practical reason and to which the positive human laws as well as the positive laws of God must be related as the historical determinations of this structure, i. e., as its completion and fulfillment.

If human and divine law are determinations of this structure, then they can be fused together into a unity in a concrete ethos. For those who believe in the revelation the "new law" becomes the formative guise of the ethos, and they see it as the fulfillment of human possibility. This leads Aquinas to conceive of the theological ethics in Summa Theologiae II-II as an ethics of virtue, in which the Aristotelian cardinal virtues are prefaced by the three divine virtues of faith, hope and love and in which all virtues find their unity insofar as they follow love, which is the "form of all virtues" (forma virtutum). ${ }^{2}$ On the basis of this structure of completion and fulfillment, the "new law" can be interpreted as the perfection of the autonomy and freedom. inherent in natural law. Those who are filled with God's spirit carry the law so perfectly within themselves that they do not need any external rules that compel them; the "new law" is the "law of freedom". 63

Thus, the Thomistic treatise on law refers the dualism of an ethos of the real world and a radical claim of the gospel, urged by Weber and Troeltsch, back into history, and, in reverse to Troeltsch's order, interprets it as a distinction between creation and promise and ascribes the task of fulfilling the promise in this time to the ethos-designing practical reason of the Christian. Since this fulfillment happens in various callings, the claim, which is inherent in the promise, remains present in its never being completely fulfilled.

\section{V}

The fifth point of the correction relates to the relationship between the doctrine of natural law and the interpretation of the social order and the individual conscience. For Troeltsch, natural law and social order are so closely bound together in Aquinas that they must be understood as a unity. According to

59 Cf. Thomas Aquinas, Summa Theologiae I-II, 98, 6; cf. also O. H. Pesch, in: Die deutsche ThomasAusgabe 13: Das Gesetz. Commentary by O. H. Pesch, Heidelberg/Graz/Wien/Köln 1977, 609-612.

60 Cf. M. Seckler, Das Heil in der Geschichte. Geschichtstheologisches Denken bei Thomas von Aquin, München 1964.

61 Cf. in. 5.

62 Cf. Thomas Aquinas. Summa Theologiae II-II, 23, 8.

63 Cf. Thomas Aquinas, Summa Theologiae I-II, 108. 
Troeltsch, the efficacy of natural law lies precisely in its ability to be extended into social philosophy. ${ }^{64}$ In this, too, Troeltsch seem to follow Thomism, particularly neo-Thomism as it was developed by catholic theology in the late 19th and early 20th century, rather than Aquinas.

Undoubtedly, for Aquinas the necessity of a social order and of political action is based in the social nature of human beings. Following Aristotle and the tradition, he says that human beings are dependent on living together with others. In contrast to plants and animals, which are led to the good by their nature and natural instincts, human beings have to identify the good with the help of reason. Because on its own it only helps them to understand the necessary and the good in general terms, and because it would be too much to expect the individual to define it in concrete terms, human beings need each other, particularly that all-embracing community that is capable of providing for everything that is necessary for life: the state. ${ }^{65}$ This clearly shows that human nature only establishes a meta-normative framework, which is to be filled out by laws, which are attained by practical deliberation and invention. Positive divine law plays a very limited role as a source of socio-philosophical and political norms. As Aquinas stresses, it only serves to lead human beings to eternal salvation. ${ }^{66}$ The realm of political action is that of the human law (lex humana). In accordance with its orientation towards the bonum commune its primary function is to establish and guarantee the external order and keep the peace so that human beings have a chance to live virtuously. ${ }^{67}$ Thus, the law of the state only prescribes rules pertaining to virtues that can be related to the common good, and only punishes actions that disturb the social existence. ${ }^{68}$

Aquinas therefore does not use the treatise on law to extend the divine law into a particular social order or concrete political actions but rather - in a kind of anticipation of Luther's doctrine of the two realms - to distinguish clearly between divine law and human law. ${ }^{69}$ As $\mathrm{O}$. H. Pesch points out, the only direct exception to this relates to the issues of freedom. ${ }^{70}$ According to Aquinas, the church may decree prescriptions to organize life within the church, but these may not be too many lest the law of freedom be turned into a burden. ${ }^{71}$ If this maxim is extended, then the "new law", i. e., the "law of freedom", results in a kind of basic rule for the design of the social order, a rule that reflects the rational and free nature of human beings as it is expressed already in the "natural law": social order and political action are to make freedom possible, not to do away with it. For Aquinas, they are conditions for the possibility of an existence in faith, and only as such they are its

64 Cf. E. Troeltsch, fn. 3., 252-358.

Cf. Thomas Aquinas, De regimine principum I, 1; In Polit. I, 1.

Cf. Thomas Aquinas, Summa Theologiae I-II, 108, 1-2.

Cf. Thomas Aquinas, In Eth. I, 1; Summa Theologiae I-II, 96, 3; 92, 2, 4; 100, 2.

Cf. Thomas Aquinas, Summa Theologiae I-II, 95-97. 
concretion. Thus, a theocratic model for social order cannot refer to Aquinas. ${ }^{72}$ For him, the state is embedded in the concrete Christian context, yet the task that he allocates to it is restricted to a function that can also be ascribed to a secular state.

Equivalent to this important, yet limited function of the state is the important, yet limited function which Aquinas assigns to the authority that rules the state: the whole-of-society is not the unity of the human species but the unity of a social order that is the result of an orientation towards the common good (bonum commune) which transcends the particular good (bonum particulare). The social authority, by positing laws, has to preserve this orientation, which does not deny the particular good but makes it possible and integrates it. ${ }^{73}$ The social order can be compared to an organism only in the sense that it is a unifying order that is to be achieved through legal and political action; authority then becomes its formative principle. ${ }^{74}$

Again it appears, that it is the doctrine of natural law and its corresponding interpretation of the relationship between moral, religious and legal demands on human action as a network of "laws" (leges) which allows Aquinas to forge a unity between different things without eliminating their differences. This is not only true for the mediation between the claim of practical reason and the claim of faith, or between individual and community, or between private and public good, but also for the mediation between objective norm and individual conscience. The multi-stage aspect in the application of practical reason, which the doctrine of natural law exhibits, allows Aquinas to understand the subjective mediation of the objective claim, or the reflexive relation contained in every moral action, in a completely new way: in the judgment of conscience (conscientia) practical reason tests its own operation, which results in the immediately action-guiding final practical judgment, against that highest principle, which it possesses as a natural and primary habit in the form of the original conscience (syndéresis), which is always without error. If the concrete action-guiding judgment turns out to be to the best of one's knowledge and conscience (in the sense of syndéresis), then it is unconditionally binding even if it is objectively erroneous. This is true even if the conscientious judgment relates to one's faith. For if to act morally is to act not arbitrarily but according to reason, i. e., from reasons, then objectively binding for me is what $I$ understand to be objectively binding. ${ }^{75}$ Thus, acting morally is always accompanied by knowledge (con-scientia) of oneself, a behaving-towards-oneself. It is not just to seize a good and thus become moral; rather, in seizing the morally good, it is primarily to seize oneself as the being that determines itself freely and through reason, and thus to become such a being. The original conscience, in which a human being grasps the highest rule of the principle of non-contrariety, is,

72 Cf. O. H. Pesch, in: Die Deutsche Thomas-Ausgabe (fn. 59) $739 f$.

Sent. 24, 2, 3-4; 39, 1-3; cf. in detail: L. Honnefelder, Praktische Vemunft und Gewissen, in. 29; also: Wahrheit und Sittlichkeit, fn. 29, $159 \mathrm{ff}$. 
in the literal sense of syndéresis, the "preservation" of the fundamental correspondence of the human being with itself, i. e., with its existence as a being of reason and freedom, which comes to realization through willing and acting. If this is taken in conjunction with the central distinction, which Aquinas accepts from Aristotle, between the good life as the ultimate goal (finis ultimus) and the individual good actions as the particular goals in which this ultimate goal is realized, $^{76}$ then conscience has to preserve not just the fundamental correspondence of my actions with the highest rule of living according to reason but also the correspondence of the particular goals with the ultimate goal which they realize. To use modern terminology, conscience thus turns out to be the medium that self-organizes my plan-for-life and keeps a check on my personal identity.

The connection between the medieval doctrine of natural law and the concept of human dignity, stated by Troeltsch, ${ }^{7}$ is therefore not at all concomitant. In Aquinas's version of the doctrine of natural law it is in fact constitutive. What Troeltsch regards as a tense union distorted by a dominance of the idea of authority to the disadvantage of the individual and its freedom, in the Thomistic elaboration on the different leges and on the multi-leveled application of practical reason turns out to be a necessary internal connection. This means, however, that the awakening of an individual conscious of itself as the real subject of moral action and the corresponding "systematic rational argument of its moral life", urged by Weber, does not only begin with ascetic Protestantism but, as Weber himself suspects, ${ }^{79}$ already in the Middle Ages. Its first expression is found in Peter Abelard's connection between the Stoic concept of conscience and Christian teaching, ${ }^{80}$ its first theoretical treatment in Aquinas's doctrine of natural law.

76 Cf. Thomas Aquinas, Summa Theologiae I-II, 1, 4-6; 89, 6; De Veritate 28, 3, 4.

7 Cf. fn. 18.

78 M. Weber, Die protestantische Ethik und der Geist des Kapitalismus, in: Ges. Aufsätze zur Religionssoziologie 1, Tübingen 71978, 125; cf. also $116 \mathrm{f}$.

79 Cf. e. g. M. Weber, fn. 78, 116f., 205.

80 Cf. Peter Abelard, Ethica, ed. D. E. Luscombe, Oxford 1971; cf. also L. Honnefelder, "Conscientia sive ratio. Thomas von Aquin und die Entwicklung des Gewissensbegriffs", in: J. Szövérffy (ed.), Mittelalterliche Komponenten des europäischen Bewußtseins, Berlin 1983, 8-19. 